\title{
The Circumstantial Relational Process Clauses in Scientific Texts in the Framework of SFL
}

\author{
Mulyati Khorina \\ Department of English, Politeknik Negeri Bandung \\ Jl. Gegerkalong Hilir, Ds. Ciwaruga - Bandung, Indonesia \\ E-mail: mulyati.khorina@polban.ac.id
}

\begin{abstract}
This paper will present the results of the study of circumstantial relational process clauses in scientific texts, especially in mechanical engineering ones. This study is aimed to identify the relational process occurring in Circumstantial relational process clauses and analyze the lexical verbs realizing the relational processes. To conduct the study, three mechanical engineering textbooks used as references by Mechanical Engineering Students of Politeknik Negeri Bandung (Polban) were used as the source for collecting the data. The method used in this study was qualitative one and Systemic Functional Linguistics (SFL) framework was applied to analyze the data. The results showed attributive relational process occur more frequently than identifying one. The attributive relational process was realized by various lexical verbs. The account of this will be presented in the rest of the his paper.
\end{abstract}

Key words: Systemic Functional Linguistics (SFL), circumstantial clauses, function, structure, identifying process, attributive process

\section{INTRODUCTION}

Relational process is one of the primary processes in Transitivity system. It is dominantly found in scientific texts (Martin, 1992) and it serves to characterize and to identify as stated by Halliday and Matthiessen (2004; 2014). This suggests that there are two types of relational process: attributive and identifying ones. The clauses below are the examples of both kinds of the relational process.

$$
\begin{aligned}
& \text { 1) Mary is smart. } \\
& \text { 2) Mary is the leader of the class. }
\end{aligned}
$$

Both of the relational processes in the clauses above are realized by lexical verb $b e$. However, they have different meanings. In clause 1), the relational process belongs to attributive one since one participant (smart) is attributed the other participant (Mary) in the clause. Whereas in clause 2), one participant (the leader of the class) serves to identify 
another participant (Mary) in the clause. Thus, it could be seen that although the processes are realized by the same lexical verb, they give different meanings to the clauses they belong to.

Furthermore, both types of the relational processes occur in three categories of relational processes clauses. They are intensive, possessive, and circumstantial relational process clauses as listed by Halliday (1994). Since this paper concerns with the third category of the clauses, the other two types of the clauses will not be discussed here.

Circumstantial relational process clauses are different from the other two clauses. Unlike the firts two types of relational process clauses whose both of their participants are realized by nominal group, circumstantial relational process clause has one participant realized by a circumstantial element. But the circumstantial element may also be manifested by the process as stated by Halliday and Matthiessen ( (M.A.K Halliday and Christian M.I.M Matthiessen, 2004) (Berg, 2017)2004; 2014). Supporting this, Eggins (2005) exemplified the clauses below.

3) The bomb was in her luggage.

\begin{tabular}{|l|l|l|}
\hline The bomb & \multicolumn{1}{|c|}{ was } & in her luggage \\
\hline Carrier & Process: attributive & Attribute \\
\hline
\end{tabular}

4) The operation lasted one hour.

\begin{tabular}{|l|l|l|}
\hline The operation & lasted & one hour \\
\hline Carrier & Process: attributive & Attribute \\
\hline
\end{tabular}

Both of the clauses above belong to circumstantial relational process clauses operating on attributive mode. However, the circumstantial element in clause 3) is represented by Attribute while in clause 4), the circumstantial element is manifested by the process. Concerning with this type of relational process clause which found in scientific texts, this paper aims to answer the following questions. 
- What type of relational process is dominated in circumstantial relational process clauses found in scientific in scientific texts?

- What lexical verbs do realize the relational process in circumstantial relational process clauses found in scientific in scientific texts?

- What types of circumstantial element realize the participant of the circumstantial relational process clauses occurring in scientific texts?

\section{LITERATURE REVIEW}

\section{Scientific Texts}

Scientific texts can be easily distinguished from other types of texts. They have special features. First, they are realized by scientific language which is free from bias as stated by Reeves (2005). Second, scientific language is realized by special lexicogrammar (Halliday, 1993). The lexicogrammar does not only become the characteristic of scientific texts but also the obstacle for learners to understand the texts. Third, Martin (1992) specified that texts with special register, such as science are dominated by identifying relational process which occurs in relational process clauses. One type of relational process clauses is called circumstantial relational process clause because it contains circumstantial elements.

\section{Circumstantial elements}

Circumstantial elements may be viewed from two points: structure and semantic. Structurally, circumstantial elements are realized by either adverbial group or prepositioanl phrase (Halliday and Matthiessen, 2014: 222). Whereas semantically, they have nine basic meanings (Table 1.).

Table 1. The nine basic types of circumstantial elements adopted by Fontaine (2013: 80) from Halliday and Matthiessen (2004:262)

\begin{tabular}{|l|l|l|l|}
\hline \multicolumn{1}{|c|}{ TYPE } & Sub-type & $\begin{array}{l}\text { Question } \\
\text { answered }\end{array}$ & Examples \\
\hline \multirow{2}{*}{ Extent } & distance & How far? & He ran three miles \\
\cline { 2 - 4 } & duration & How long? & He ran for three days \\
\hline
\end{tabular}




\begin{tabular}{|c|c|c|c|}
\hline & frequency & How frequently & He ran every day \\
\hline \multirow{2}{*}{ Location } & Place & Where? & He ran in Toronto \\
\hline & Time & When? & He ran last year \\
\hline \multirow{4}{*}{ Manner } & Means & By what means? & He saved her with a rope \\
\hline & Quality & How? & She saved him quickly \\
\hline & Comparison & Like what? & She ran like the wind \\
\hline & Degree & How much? & $\begin{array}{l}\text { She loved him more than } \\
\text { anyone }\end{array}$ \\
\hline \multirow{3}{*}{ Cause } & Reason & Why? & She ran because she loved to \\
\hline & Purpose & $\begin{array}{l}\text { For what } \\
\text { purpose? }\end{array}$ & She ran to raise money \\
\hline & Behalf & $\begin{array}{l}\text { On whose } \\
\text { behalf? }\end{array}$ & She ran for her sister \\
\hline \multirow{3}{*}{ Contingency } & Condition & $\begin{array}{l}\text { Under what } \\
\text { condition? }\end{array}$ & $\begin{array}{l}\text { In the event of fire leave the } \\
\text { building }\end{array}$ \\
\hline & Default & $\begin{array}{l}\text { Under what } \\
\text { negative } \\
\text { condition }\end{array}$ & $\begin{array}{l}\text { Without an agreement, the plan } \\
\text { will fall }\end{array}$ \\
\hline & Concession & $\begin{array}{l}\text { With what } \\
\text { concession? }\end{array}$ & Despite her help, the plan failed \\
\hline \multirow[b]{2}{*}{ Accompaniment } & Comitative & Who/what with? & John ran with Jane \\
\hline & Additive & Who/what else? & $\begin{array}{l}\text { John wears mitten in addition to } \\
\underline{\text { his gloves }}\end{array}$ \\
\hline
\end{tabular}




\begin{tabular}{|l|l|l|l|}
\hline \multirow{2}{*}{ Role } & Guise & What as? & She spoke as his mentor \\
\cline { 2 - 5 } & Product & What into? & $\begin{array}{l}\text { He was transformed into a } \\
\text { prince }\end{array}$ \\
\hline \multirow{2}{*}{ Matter } & Matter & What about? & He warned me about the film \\
\hline \multirow{2}{*}{ Angle } & Source & $\begin{array}{l}\text { According to } \\
\text { whom? }\end{array}$ & $\begin{array}{l}\text { According to the lecturer, the } \\
\text { class is cancelled }\end{array}$ \\
\cline { 2 - 4 } & Viewpoint & $\begin{array}{l}\text { From whose } \\
\text { viewpoint/ } \\
\text { perspective? }\end{array}$ & To me, he's an idiot \\
\hline
\end{tabular}

(Martin J. , 1992)

\section{Circumstantial relational process clauses: their characteristics}

Like other types of relational process clauses, circumstantial relational process clause also operates on two types of relational processes: attributive and identifying. Each of them possesses its own characteristics as listed by Halliday and Matthiessen (2014).

Circumstantial relational process clause operating on attributive mode has characteristics as follows.

- The participants involved in the clause are Carrier and Attribute.

- Carrier is realized by nominal group but Attribute is realized by prepositional phrase or by nominal group.

- The circumstantial element may be construed in Attribute or in process.

- The clause is not reversible.

Here are the examples of circumstantial relational clauses operating on attributive mode. 
5) My story is about a poor shepherd boy.

\begin{tabular}{|c|c|c|}
\hline My story & is & about a poor shepherd boy \\
\hline Carrier & Process & Attribute: circumstance (Matter) \\
\hline Nominal group & Verbal group & Prepositional phrase \\
\hline
\end{tabular}

6) My story concerns a poor shepherd boy.

\begin{tabular}{|c|c|c|}
\hline My story & concerns & a poor shepherd boy \\
\hline Carrier & $\begin{array}{c}\text { Process: } \\
\text { circumstantial }\end{array}$ & Attribute: circumstance (Matter) \\
\hline Nominal group & Verbal group & Nominal group \\
\hline
\end{tabular}

Clause 5) is circumstantial relational process clause working on attributive mode. The attributive relational process is realized by verb be. Having attributive relational process, the participants involved in the clause are Carrier and Attribute. Carrier is realized by nominal group My story while Attribute is realized by prepositional phrase about a poor shepherd boy. This prepositional phrase is a type of circumstantial element which functions as a Matter. This explains the matter of the entity found in Carrier. However, in clause 6), circumstantial element is manifested by the relational process which is realized by verb concerns. Whereas Attribute functioning as matter is realized by nominal group. Thus, circumstantial element is not only construed by Attribute but also by process.

Meanwhile, identifying circumstantial relational process clause own some properties.

- The inherent participants involved in this kind of clause are Token - Value.

- Token is commonly realized by nominal group as in attributive clause and Value may be realized by the same structure as Attribute serving one of the circumstantial elements listed in Table 1. 
- The circumstantial element may be manifested either by Value or by process.

- The clause has reversible version.

7) Tomorrow is the tenth.

\begin{tabular}{|c|c|c|}
\hline Tomorrow & is & the tenth \\
\hline Token & Process & Value \\
\hline Nominal group & Verbal group & Nominal group \\
\hline
\end{tabular}

8) A bikeway also circles the Village.

\begin{tabular}{|c|c|c|}
\hline A bikeway & circles & The Village \\
\hline Token & Process & Value \\
\hline Nominal group & Verbal group & Nominal group \\
\hline
\end{tabular}

Clause 7) and 8) are circumstantial relational process clauses operating on identifying mode. The former clause has identifying process realized by lexical verb $b e$. Consequently, the circumstantial element is realized by Value which is nominal group. This nominal group serves circumstantial meaning of Time. Whereas in clause 8), the circumstantial element is construed by the process realized by lexical verb circles. This verb informs about Manner, a type of circumstantial element. Working on identifying mode, both of these clauses can be reversed without changing the meaning. They become: The tenth is tomorrow and The Village is circled by a bikeway.

\section{METHODOLOGY}

Method used in this study is a qualitative method in which quality is important. Quality is defined as the what, how, when, where, and why of a thing-its essence and ambience, thus, qualitative research is the meanings, concepts, definitions, characteristics, metaphors, symbols, and descriptions of things Lune and Berg (2017). 
This suggests that the data may be in the form of texts or documents. The data for this study were collected from textbooks aimed for mechanical engineering students. They are Mechanical Engineering Principles, An Introduction to Mechanical Engineering, Shigley's Mechanical Engineering Design, and Welding Principles and Application.

The data taken from the textbooks were analysed descriptively based on the approach discussed above. First, all circumstantial relational process clauses were selected. Then, the selected clauses were classified according to the relational process they own. After that, the classified data were categorized in terms of the type of circumstantial elements. The clauses were analyzed based on circumstantial element realizing the participant. Finally, the conclusion was drawn. The stages of the data analysis are illustrated in the figure below.

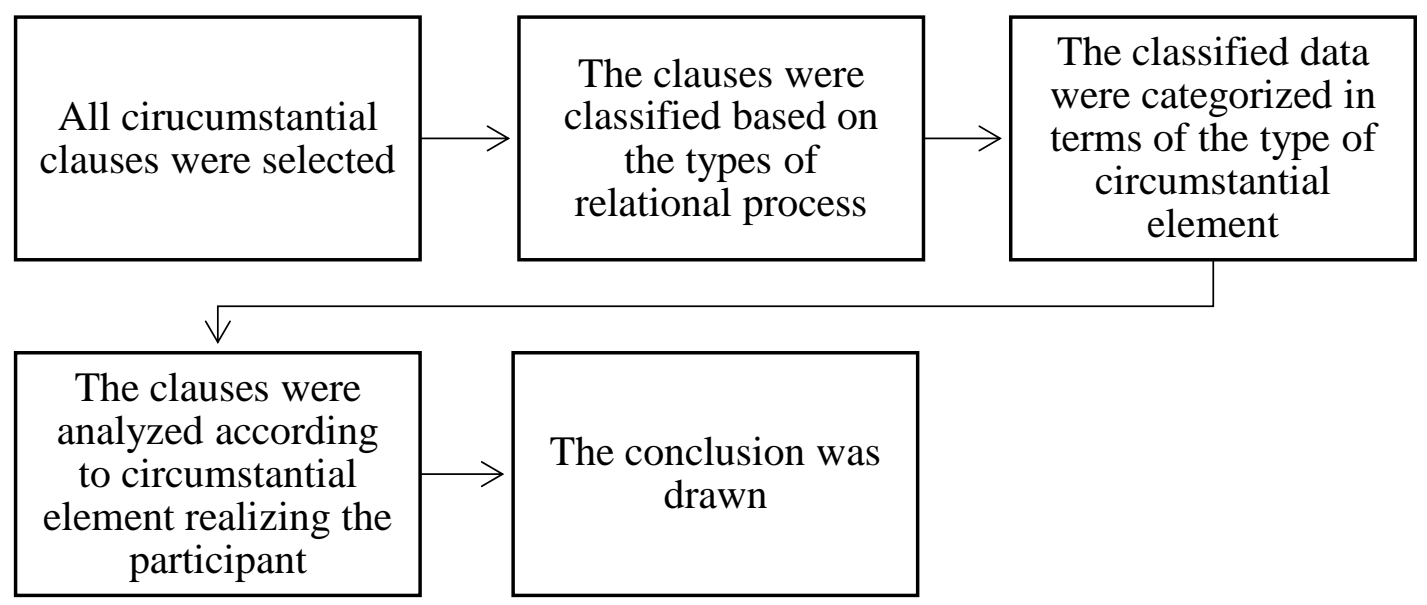

Figure 2. The process of data analysis

\section{RESULTS AND DISCUSSION}

A total of 45 circumstantial relational process clauses were found. 44 clauses operate on attributive relational process and only one clause which operates on identifying mode. The attributive relational process is realized by seven lexical verbs while identifying one is realized only by single lexical verb (Figure 3.). 


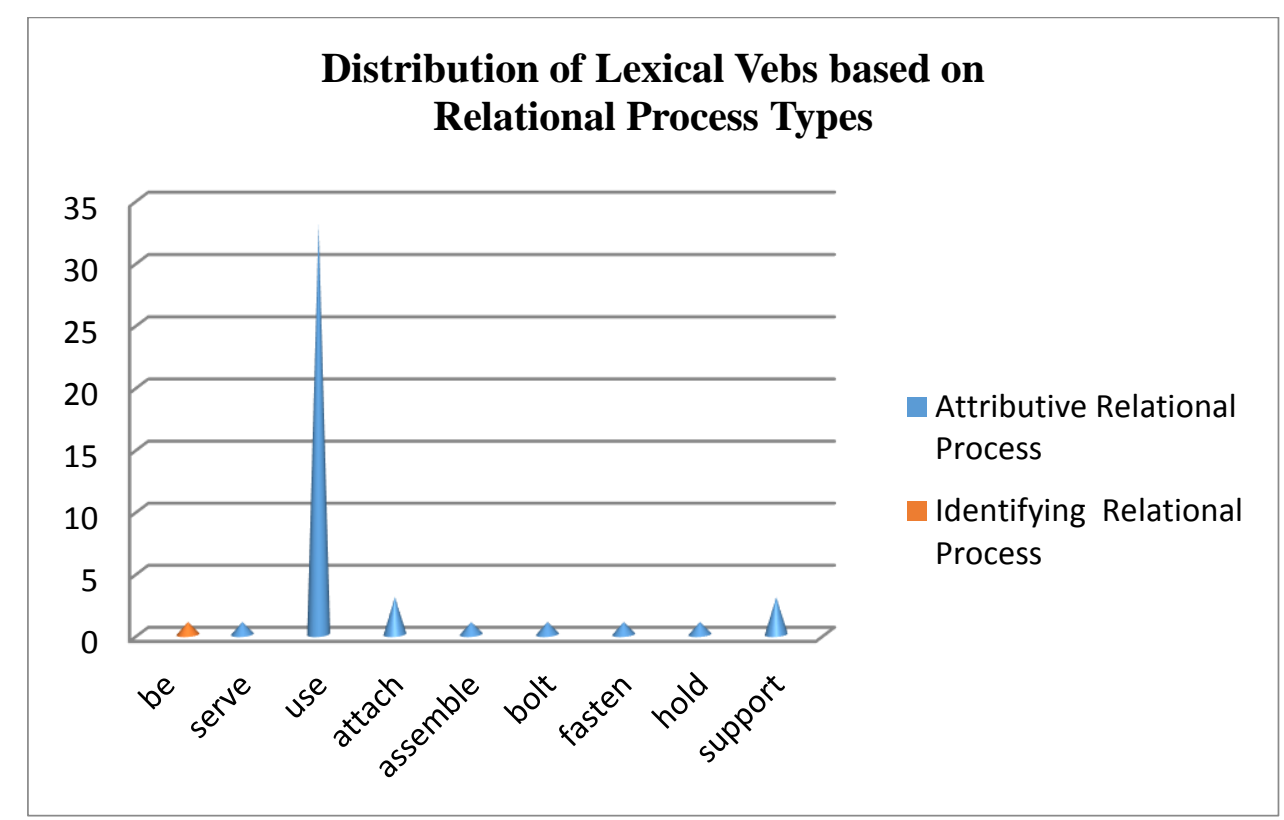

Figure 3. Distribution of lexical verbs based on relational process types

Another finding is there are four types of circumstantial element found in the data (Figure 4.). They are means, Place, Purpose, and Guise. Among the them, Purpose is the dominant circumstantial element that occur in the data.

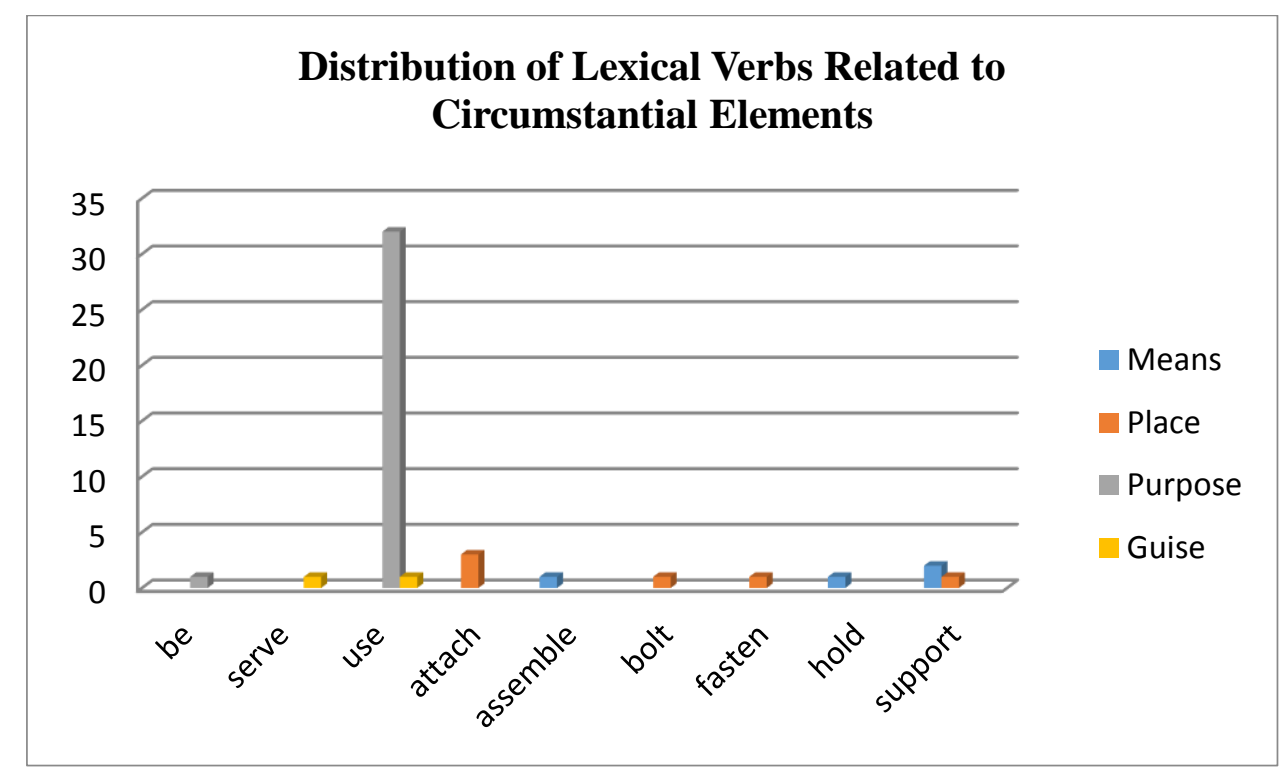

Figure 4. Distribution of lexical verbs related to circumstantial element

Based on the data above, it is implied that circumstantial relational process clauses occurring in scientific texts tend to work on attributive mode realized by various lexical 
verbs. Further discussion to answer the research questions previously formulated is presented below. .

\section{Circumstantial relational process clause: circumstantial element of Purpose}

As previously presented, attributive relational process is the kind of process occuring the most frequently. The process is dominantly realized by lexical verb use. There are 33 clauses containing this verb. The clauses containing this verb tend to have Attribute realized by circumstantial element of Purpose and Guise (Figure 4.). The circumstantial element of Purpose may be realized either by prepositional phrase containing preposition to as in clause 1. -3 . or preposition for as in clauses 4. -5 . When the prepositional phrase is initiated by preposition to, it is followed by invinitive verb. When it begins with preposition for, the verb that follows should be in gerund or in ingform. This can be seen clearly in the following table of analysis.

\begin{tabular}{|c|c|c|c|}
\hline 1 & Percentages & are used & to give a common standard. \\
\hline 2 & Vise and clamps & are used & to hold the workpiece securely \\
\hline 3 & An electric motor & is used & to power an exercise treadmill \\
\hline 4 & $\begin{array}{c}\text { A milling machine } \\
\text { (mill) }\end{array}$ & is used & $\begin{array}{c}\text { for machining the rough surfaces } \\
\text { of a workpiece }\end{array}$ \\
\hline 5 & $\begin{array}{c}\text { A milling machine } \\
\text { (mill) }\end{array}$ & is used & for cutting slots, grooves, and hole \\
& $\begin{array}{c}\text { Nominal group } \\
\text { Carrier }\end{array}$ & Verbal group & Prepositional phrase \\
\hline & attributive & Attribute \\
\hline
\end{tabular}

To probe that these prepositional phrases are classified as circumstantial element of Purpose, question like "What is the purpose of Percentages/Vise and clamps/ An electric motor/ A milling machine (mill)/ A milling machine (mill)? can be applied. The answer is found in Attribute. 
Also found in the data that circumstantial element of Purpose may also appear to realize not only Attribute but also Value. Consequently, circumstantial relational process clause operates on identifying mode. This can be seen in the table of analysis below.

\begin{tabular}{|c|c|c|c|}
\hline 6 & $\begin{array}{c}\text { The purpose of } \\
\text { quenching }\end{array}$ & are & to harden the steel \\
\hline & Nominal group & Verbal group & Prepositional phrase \\
\hline & Token & Process: identifying & Value \\
\hline
\end{tabular}

Since the clause works on identifying mode, it has reversible version. Value realized by prepositional phrase comes first before identifying process. Then Token realized by nominal group comes after the process. The clause becomes:

To harden the steel is the purpose of quenching.

\section{Circumstantial relational process clause: circumstantial element of Guise}

Besides, circumstantial clause operating on attributive mode realized by lexical verb use may also have Attribute realized by circumstantial element of Guise as in clause 7. Unlike the previous data, the circumstantial element of Guise is realized by adverbial group. To probe the clause, the question "What are Ceramics used as" is applied. The answer is "thermal barrier coatings" which can be found in Attribute. This can be seen clearly in the table of analysis below.

\begin{tabular}{|c|c|c|c|}
\hline 7 & Ceramics & are used & as thermal barrier coatings \\
\hline & Nominal group & Verbal group & Adverbial group \\
\hline & Carrier & Process: attributive & Attribute \\
\hline
\end{tabular}




\section{Circumstantial relational process clause: circumstantial element of Means}

The following clauses are circumstantial relational process clauses which have attributive relational process. The attributive relational process is realized by lexical verbs support (8-9) and assemble (10). Although the relational process is realized by different verbs, all the clauses own Attribute realized by circumstantial element of Means. It is indicated that the circumstantial elements are realized by prepositional phrases. This can be probed with the question "By what means (Carrier) is supported/are assembled?" The answer will be found in Attribute, the other participant. The table analysis below indicates it clearly.

\begin{tabular}{|c|c|c|c|}
\hline 8 & The shaft & is supported & $\begin{array}{c}\text { by ball bearings on each side of the } \\
\text { belt }\end{array}$ \\
\hline 9 & $\begin{array}{c}\text { A two-tier system } \\
\text { to repair bridge } \\
\text { infrastructure }\end{array}$ & is supported & $\begin{array}{c}\text { by two steel cables for each } \\
\text { platform }\end{array}$ \\
\hline 10 & The shells & are assembled & by clamping, bolting, or pasting \\
\hline & Nominal group & Verbal group & Prepositional phrase \\
\hline & Carrier & Process: attributive & Attribute \\
\hline
\end{tabular}

\section{Circumstantial relational process clause: circumstantial element of Place}

The data also show that circumstantial relational process clauses operate on attributive mode realized by lexical verbs support (11), attach (12-14), fasten (15), or bolt (16). These lexical verbs manifest the circumstantial elements which require circumstantial elements of Purpose. This type realized by prepositional phrases represent Attribute. To probe the circumstantial element of Purpose, the question " is/are (Carrier) supported/attached/fastened/bolted?" The answer will be represented by Attribute as indicated in the table of analysis below. 


\begin{tabular}{|c|c|c|c|}
\hline 11 & The workpiece & is supported & on a table \\
\hline 12 & A spool & is attached & to the rear axle \\
\hline 13 & The output gear & $\begin{array}{c}\text { is directly } \\
\text { attached }\end{array}$ & to the front drive axle \\
\hline 14 & The spur gear & is attached & to the 1-in.-diameter shaft \\
\hline 15 & The eyebolt & is fastened & to a thick base plate \\
\hline 16 & Three tension rods & are bolted & to a gusset plate \\
\hline & Nominal group & Verbal group & Nominal group \\
\hline & Carrier & Process: & Attribute \\
& & attributive & \\
\hline
\end{tabular}

\section{CONCLUSION}

Having presented the discussion of circumstantial relational process clauses in scientific texts above, it can be drawn some conclusions. First, circumstantial relational process clauses dominantly operate on attributive mode. The attributive relational process is realized by lexical verbs use, serve, support, hold, attach, fasten, bolt and assemble. The majority of attributive relational process is realized by lexical verb use. Whereas identifying relational process is realized by single lexical verb, that is $b e$. It is also found that there are four types of circumstantial element which represent Attribute. They are circumstantial element of Purpose, Means, Guise, and Place, among which Purpose has the most frequent occurance.

\section{ACKNOWLEDGEMENT}

This paper is based on the research funded by Polban under contract number 1074.1/PL1/LT/2016 


\section{REFERENCES}

Berg, H. L. (2017). Qualitative Research Methods for the Social Sciences, 9th Edition. Essex: Pearson Education Limited.

Eggins, S. (2005). An Introduction Systemic Functional Linguistics. London: Continuum.

Fountaine, L. (2013). Analysing English Grammar. Cambridge: Cambridge University Press.

Jeffus, L. (2012). Welding: Principles and Applications. New York: Delmar Cengage Learning.

Lewis, J. W. (2013). An Introduction to Mechanical Engineering. Stamford: Cengage Learning.

M.A.K Halliday and Christian M.I.M Matthiessen, 3. E. (2004). Introduction to Functional Grammar. London: Hodder Education.

Martin, J. (1992). English Text: System and Structure. Amsterdam: John Benjamins Publishing Company.

Martin, M. H. (1993). Writing Science: Literacy and Discursive Power. London: The Falmer Press.

Matthiessen, M. H. (2014). An Introduction to Functional Grammar. Oxon: Routledge.

Nisbett, R. G. (2015). Shigley's Mechanical Engineering Design. New York: McGrawHill Education.

Ross, J. B. (2015). Mechanical engineering principles. Oxon: Routledge. 